\title{
English Language Teaching in Brazil: A Gap in Policy, Problems in Practice
}

\author{
Fernanda C. A. Batista ${ }^{1}$ \\ ${ }^{1}$ Faculty of Education, York University, Toronto, Canada \\ Correspondence: Fernanda C. A. Batista, Faculty of Education, York University, Toronto, Canada. E-mail: \\ fcabatista@hotmail.com
}

Received: June 2, 2020

Accepted: June 17, 2020

Online Published: July 17, 2020

doi: $10.5539 /$ elt.v13n8p135

URL: https://doi.org/10.5539/elt.v13n8p135

\begin{abstract}
Only three percent of Brazilians are estimated to speak English despite the status of this language as a mandatory subject in grades 10 to 12 of basic education and preferred foreign language in grades 5 to 9 . This paper will analyse possible reasons for this fact. The widespread concept in the Brazilian society that speaking English is beneficial to individuals because it provides access to the globalised world does not seem to be enough to promote the actual learning of the language by the majority of the population, and it is argued here that this fact has to do with a gap in the foreign language teaching policy documents: the 2015 National Education Guidelines and Framework Law (LDB 2015), the Brazilian National Curriculum Parameters for Primary Education (PCN-EF), and the Brazilian National Curriculum Parameters for Secondary Education (PCN-EM). These documents do not prescribe the necessary conditions for English Language Teaching (ELT) to take place effectively, but, instead, provide suggestions for teachers on how to adapt to the status quo, which means focusing on reading to the detriment of the other aspects of the English language due to a number of factors ranging from a lack of resources to a large number of students per class.
\end{abstract}

Keywords: ELT, basic education, Brazilian education system

\section{Introduction}

Brazil is a South American country which has Portuguese as its official language as a result of the colonisation process to which it was subjected from the late fifteenth century to the early eighteenth century, when Portugal dominated the land and decimated most native indigenous populations and their languages. It is estimated that 97.9 percent of the approximately 210 million Brazilians have Portuguese as their primary language, 1.9 percent have German as their primary tongue (mostly within the German colonies that were established in the country during World War II), and 0.2 percent have an indigenous language as their first language. Also, five per cent of the population is estimated to speak an additional language, three per cent of whom has English as an additional language (World Atlas, 2019).

Despite the fact that these numbers indicate that Brazil is a largely monolingual nation, the idea that speaking a foreign language, especially English, is beneficial to individuals as well as to the Brazilian society as a whole is common sense in the media and among people in all sectors of the country due to a number of reasons. First, according to Rajagopalan (2003), 'there is indeed a widespread perception that it [English] is the language of the globalised world and a passport to professional success and better job opportunities' because 'a working command of the language is often stipulated as a prerequisite for most white collar jobs (and some blue collar ones as well) or, at the very least, understood as an additional feather in the applicant's cap' (p. 94). Moreover, universities in Latin America are being pressured to internationalise their research and teaching in order to keep up with the academic debate, which takes place primarily in English through publications in this language (Hamel at al., 2016). Additionally, as noted by Gnerre (as cited in El-Dash and Busnardo, 2001), linguistic varieties (and languages) are seen to be worth what their speakers are worth in society because they reflect the power and authority of the speakers in economic and social relations, and English presently occupies 'the highest position in the international scale of values' (p. 60).

The teaching of foreign languages is mandatory in the Brazilian basic education system in grades 5 to 12 and is informed by this idea that the English language holds high status. However, the effectiveness of English Language Teaching in basic education is very low, as the percentage of actual speakers of this language shows, and this paper, 
therefore, aims at discussing some of the possible causes for such numbers: the policies are incomplete and this fact impacts the quality of teacher education, the availability of pedagogical resources, the number of students in the classroom, and both students' and teachers' motivation and attitude toward English.

This analysis of the situation of ELT in Brazil will take place through an activation of the knowledge acquired from my own experience as a teacher student, teacher, and later professor of teacher education and the review of eight journal articles that address the problem as well as of three of the most important education policies in the country: the 2015 National Education Guidelines and Framework Law (Lei de Diretrizes e Bases (LDB) 2015); the Brazilian National Curriculum Parameters for Primary Education (PCN-EF); and the Brazilian National Curriculum Parameters for Secondary Education (PCN-EM). Three journal articles as well as the three policy documents were written in the Portuguese language and had some of their ideas and extracts translated into English by me in citations and quotations.

\section{A Gap in Brazilian Education Policies}

The most important policy document guiding Brazilian education at present is LDB 2015. It states that basic education can be either publicly or privately funded and consists of pre-school (targeted at children aged 0 to 5 , but mandatory to children aged 4 and 5), mandatory primary school (grades 1-9, children aged 6-14), and mandatory secondary school (grades 10-12, adolescents aged 15-17). LDB 2015 mandates the teaching of a foreign language chosen locally from grades 5 to 12 for two 45-, 50-, or 60-minute-periods per week in all basic education (Brazil, 2014). A recent reform has added to LDB 2015 that English will be the foreign language taught in secondary school throughout the country. Previous versions of LDB, however, did not mandate the teaching of English or any other foreign language in basic education, and the problems that are faced in ELT nowadays can be said to date back from the time these laws were passed (Messias, 2012; Silva, 2015).

For instance, LDB 1961 removed foreign languages from the list of compulsory subjects in secondary education, LDB 1971 removed them from the subjects in primary education while making them optional in secondary education for one 45-, 50-, or 60-minute-period per week, and LDB 1976 made them optional in primary school and mandatory in secondary school (Messias, 2012). It is worth mentioning that, by 1961, English had already been established as the most commonly taught foreign language in Brazilian schools and that this removal of / reduction in English classes led to an increase in the number of private language centres in Brazil as well as to the perception that only in those language centres could students learn the English language (Messias, 2012; Paiva, 2003, as cited in Silva, 2015; Capuani and Venera, 2016). This idea is ingrained in Brazilian society to such an extent until the present day that it becomes a self-fulfilled prophecy even when good conditions for learning seem to be present and is reinforced by this and other important policy documents - PCN-EF and PCN-EM - when they do not establish the conditions that are necessary for the teaching and learning of a foreign language to happen successfully in basic education (Gimenez et al., 2016), but rather attempt to adjust the teaching and learning to whatever the existing conditions are, which can be interpreted as a way to promote not only the status quo (Messias, 2012) but also a neoliberalist view of English language learning (Capuani and Venera, 2016).

Both PCN-EF (Brazil, 1998) and PCN-EM (Brazil, 2000) present progressive ideas about how a foreign language should be taught in the basic education classroom. Such ideas include a social interactionist view of language, which aligns with contemporary research in second language teaching and means a shift from the traditional grammar-translation method largely employed in Brazilian schools in previous decades. The Parameters also recommend interdisciplinary work, the implementation of cross-curricular themes, formative assessment in addition to summative, a value of students' prior knowledge and position as critical subjects, and, thus, an approach to teaching as negotiation that aims to educate students for the full exercise of citizenship, which includes the notions of respect for difference and diversity that can be promoted by the teaching and learning of foreign languages.

However, the Parameters fail in pointing out the necessary conditions for this teaching and learning process to occur. For example, they acknowledge that reading and writing should be focused on to the detriment of listening and speaking due to the difficulties faced by the teacher in basic education (Brazil, 1998): large classrooms, lack of appropriate resources including class and preparation time for the teacher and opportunities for the students to be exposed to the language outside the classroom, and, in many situations, teachers' lack of knowledge of the subject matter. Instead, what they should do is to actively propose that a smaller number of students sit in English classes - as it was allowed by LDB 1996 and continues to be so by LDB 2015, that more class and preparation time be granted the teacher, that schools have English resources that students can access to familiarise themselves with the language, and that better teacher education be implemented. When neither PCN-EF nor PCN-EM provides solutions to the obstacles for satisfactory ELT in basic education and yet acknowledge that knowing a foreign 
language is beneficial, they are implicitly promoting the privatisation of ELT because they are directing students to private language centres (Capuani and Venera, 2016). There are several problems with this position given that the right to free education provided by the state is guaranteed by the Brazilian constitution.

First, about 70 per cent of Brazilians come from social classes C, D, and E (Nes, 2016). This means that many of these people would not be able to afford private language courses for themselves or their children. Actually, this percentage is similar to the one of students attending public schools in Brazil, which are free. Privatising ELT for these children, then, pretty much means accepting that they will never learn the language and, if it is really such an important means of inclusion in the global world, that they will be excluded. This is the most undesirable of things for an already really unequal society which has problems with extreme poverty, infant mortality, corruption, violence, and high crime rates, among others. Second, this underlying outsourcing of ELT contradicts the policy documents themselves, which state that learning a foreign language is the right of all citizens (LDB 2015) and that the teaching of a foreign language is the duty of primary and secondary schools and should take place in these settings (PCN-EF). Third, even those students whose families can afford private language courses would be paying for the same service twice if studying in public schools and three times if studying in private schools while receiving it only once and not in the place guaranteed to by Brazilian laws, which is also not fair. These students are likely be demotivated in English classes in both places, perhaps, but in basic education classes for sure, since they tend to have a slower pace. Fourth, the justification for the inclusion of English classes in the curriculum itself becomes hard if language learning outcomes are non-existent. Such absence may lead to the idea that these lessons are taking time that could be used to teach something else, or - worse - contribute to the already widespread notion that everything else is just as poor quality as these classes, and that formal schooling is pointless except for the fact that it grants individuals certificates of completion at the end of the process so that they can enter university and the job market. This, in turn, may increase - and later be increased by - the disbelief in the whole education system, which can cause students to be undisciplined and teachers to burn out.

\section{Problems in the Teaching of English in Brazilian Schools}

For any educational policy to be successfully enacted, teachers have to be informed and willing to put the policies into practice and, from a work-ethics perspective, they should be both. This does not mean that teachers do not have academic freedom or that they cannot be critical of the policies which they are entrusted to enact, but that they need to share the values of the institutions where they work, which, in Brazilian basic education would encompass the schools themselves, the school boards, and the Ministry of Education. In practical terms, this means that teachers need to be knowledgeable of the system in which they are inserted as well as of the outcomes established by the national guidelines and parameters, and engaged in doing their best to achieve those outcomes. The way for teachers to achieve such outcomes is through classroom work with their subject matter, and, therefore, it should be needless to say that they are supposed to be knowledgeable of that first and foremost. With regards to ELT in Brazilian basic education, though, there is a need to say it because many English teachers in this system do not speak the language.

The reasons why many English teachers in Brazil do not speak the language vary, but a very important one is that most undergraduate programs only offer a dual major, one for the teaching of English and another for the teaching of Portuguese, and many aspiring teachers enrol in these programs because they actually want to teach Portuguese language and literature. This leads to a lack of interest in learning the English language, which they do not intend to teach until, after they graduate, there is a shortage of Portuguese classes available in their schools or school boards due to the large number of graduates and the fierce competition for these classes. As a consequence, these teachers are often not aware of the academic debate regarding the efficient methods for the teaching of English as a second or foreign language and reproduce in their classrooms the approaches in which they were taught as basic education students themselves and that they are able to lead considering their language skills. Also, they tend not to take the job seriously enough so as to research and learn as they go because they see it as a temporary 'side job', since their 'real job' is teaching Portuguese.

This problem is not only the individual's fault. It can be seen as a systemic problem among undergraduate programs that grant teaching degrees to people who are not capable of teaching, and it happens because the standards tend to be pretty low in higher education as well when it comes to English, with reading being given more emphasis than the other skills. Therefore, if an individual can minimally read in English, they are likely to succeed in completing their ELT program. The question that strikes those witnessing these facts is 'how can these teachers get English classes assigned to them when they do not speak the language?' The answer is twofold: 1-) Who can tell whether a person is competent in the language or not? Only another competent user of it, and there are not that many in Brazil (only about 3 per cent of the population). Therefore, if a person holds a degree and is already in the school teaching another subject, others will automatically assume that they are somewhat 
knowledgeable and trust them to teach English if need be; 2-) The mindset that 'any class is better than no class', which means that even if school managers do not trust the Portuguese teacher's English skills, it is better to have these teachers do whatever they can than cancelling English classes due to the absence of a teacher.

This being said, it is important to acknowledge that in the Brazilian scenario many English teachers are actually qualified and willing to teach the language, and yet the quality of lessons cannot overall be said to be good enough so as to teach students the language. The causes of that are the lack of the necessary structure in Brazilian classrooms, the large number of students per class, and the lack of student motivation, which can lead to a lack of teacher motivation as well. All of these problems could be remedied if the policies discussed previously actively indicated how to fix them and efforts were made to implement the policies.

Most schools in Brazilian basic education, both public and private, are equipped with desks and chairs, blackboards/whiteboards, and chalk/markers. In addition to those, some schools have a computer, a data projector, loudspeakers, and internet connection for the teachers to use in their lessons if they request them, which means the devices are not preinstalled in every classroom and, therefore, teachers need to book them beforehand, having their attempts sometimes conflict with other teachers' bookings. Few schools have this audiovisual equipment installed in every classroom for teachers to use in all lessons that they see fit. Also, most schools provide printing and photocopying services, but there is usually a limit as to the number of pages a teacher can print and photocopy per month or term. This fact shows why many English teachers would end up sticking to the textbook most of the time, which is a widely used resource in primary and secondary schools. This reality has been changing, though, with the spread of smartphones among the student population, as more teachers are exploring this device as pedagogical tools in their classes.

Nonetheless, there are limitations regarding the extent to which teachers can make use of cellphones in Brazilian classes, including the difficulty in monitoring and keeping all students on task. Classes are large, with generally 35 to 45 students who can get sidetracked easily regardless of whether they are working with textbooks or more engaging resources such as phones. Distraction is something many teachers (not only of English) treat as indiscipline and about which they complain for hindering the teaching and learning process. It is, however, a somewhat normal feature of young students that can be managed if teachers are aware of cognitive and emotional development theories. Nevertheless, the most efficient way to prevent that from happening and encourage oral participation in the foreign language would be to limit the number of students in the same class to less than 20, and this is something that is beyond the teacher's power to do. With regards to indiscipline, though, teachers of all subjects may face it from students due to a cultural characteristic of not valuing schooling or the teacher as a role model, and English teachers, in addition to that, may face it due to a lack of motivation toward and even resistance to the language itself.

Such lack of motivation comes from misconceptions about the English language among learners. One of these misconceptions is that English is the language of England and the United States only and, therefore, that there is no point in learning it if one is not to go to these places (Pereira, 2016). Another misconception is that foreign languages can only be successfully learnt in private language schools and - preferably - outside Brazil (Pereira, 2016). Ways in which these misconceptions can and should be corrected are suggested in the PCN-EF and PCN-EM and include teachers taking an intercultural approach to ELT 'to make the study of this foreign language less form based and more socially and culturally relevant' with the goal of raising awareness of 'the global web in which English is involved' (as cited in Pereira, 2016, p. 579). Another way to change this idea is to prove it wrong by actually teaching the language, which takes a review of policies and a reform in the English language classroom.

\section{Discussion}

Brazil is a big country which is considered to be largely monolingual, with Portuguese being the native language of almost 98 percent of the population. This is due to the colonisation process to which it was subjected by Portugal for over three centuries. This reality, however, does not stop all sectors in the country from understanding that the knowledge of a second language, especially English, is important in a global world as is today's. The foreign language education policies in place, on the other hand, hinder the acquisition of a foreign language by the majority of the population because they do not prescribe the necessary conditions for successful teaching and learning of foreign languages to happen in basic education and, as a result, although foreign language classes (English in grades 10-12 and a foreign language locally chosen in grades 5-9) are mandatory, they are not effective in teaching students the language studied.

The National Education Guidelines and Framework Law, The Brazilian National Curriculum Parameters for Primary Education, and The Brazilian National Curriculum Parameters for Secondary Education need to be 
reviewed so as to include the missing information and allow for the objectives that they themselves have set to be achieved. Until they do so, ELT in basic education will be undervalued because it will be offered to students who do not believe in it and by teachers who cannot make it happen due to this student mindset, but also to the fact that they themselves are not always qualified, and, even when they are, do not have the necessary resources to teach all language skills and have to deal with too many students at a time in crowded classes. It will continue to happen in private language centres, though, which is not a problem itself but paints an alarming picture of the Brazilian society given the fact that private institutions charge tuition from students, that most Brazilians belong to the lower social classes who may not be able to afford such complementary education, and that these Brazilians will continue to be denied the opportunity to fully participate in the global world, be it through the internationalisation of higher education, the access to good jobs that have the knowledge of English as a prerequisite, or the awareness of different cultures and the resulting better understanding of the self. For a country committed to reducing the educational, social, and economical gap between its richest and poorest citizens, such picture should be unacceptable.

\section{Acknowledgements}

The author would like to thank Dr. Qiang Zha, who taught the course Issues in Globalization and Education in the Faculty of Education at York University in the Summer 2019, for which this research was conducted, and Dr. John Ippolito, who read and approved this paper to count towards the completion of my Language and Literacy Education Diploma.

\section{References}

Brazil. (1998). Parâmetros curriculares nacionais: terceiro e quarto ciclos do ensino fundamental: língua estrangeira [Brazilian National Curriculum Parameters for Primary Education: Foreign Language]. Secretaria de Educação $\quad$ Fundamental. Brasília $\quad$ : http://portal.mec.gov.br/seb/arquivos/pdf/pen_estrangeira.pdf

Brazil. (2000). Parâmetros Curriculares Nacionais: Ensino Médio: linguages, codigos e suas tecnologias [Brazilian National Curriculum Parameters for Secondary Education: Languages, Codes, and Related Technologies]. MEC: Brasília. http://portal.mec.gov.br/seb/arquivos/pdf/blegais.pdf

Brazil. (2014). LDB 2015: LDB: Lei de Diretrizes e Bases da Educação Nacional [recurso eletrônico]: Lei no 9.394 , de 20 de dezembro de 1996, que estabelece as diretrizes e bases da educação nacional [2015 National Education Guidelines and Framework Law]. 9. ed. Brasília: Câmara dos Deputados, Edições Câmara. http://bd.camara.leg.br/bd/bitstream/handle/bdcamara/19339/ldb_12ed.pdf? sequence=37

Capuani, R. S., \& Venera, R. A. S. (2016). Uma análise dos PCNS de ensino do inglês: discursos em disputa. [An analysis of English teaching PCNs: discourses in dispute]. The ESPecialist, 37(2), 117-134. https://revistas.pucsp.br/index.php/esp/article/view/11788

El-Dash, L. G., \& Busnardo, J. (2001). Brazilian Attitudes toward English: Dimensions of Status and Solidarity. International Journal of Applied Linguistics, 11(1), 57-74. https://doi.org/10.1111/1473-4192.00004

Gimenez, T., Ferreira, A. J., Alves Basso, R. A., \& Carvalho Cruvinel, R. (2016). Policies for English Language Teacher Education in Brazil Today: Preliminary Remarks. Profile, 18(1). http://dx.doi.org/10.15446/profile.v18n1.48740

Hamel, R. E., Lopez, E. A., \& Carvalhal, T. P. (2016). Language Policy and Planning: Challenges for Latin American Universities. Current Issues in Language Planning, 17(3-4), 278-297. http://dx.doi.org/10.1080/14664208.2016.1201208

Messias, C. (2012). O ensino de língua inglesa na legislação educacional brasileira. [The English Teaching in the Brazilian Educational Legislation]. KUR'YT'YBA: Revista Cientifica do Colégio Militar de Curitiba, 3: 97-108.

https://www.academia.edu/24474197/O_Ensino_de_L\%C3\%ADngua_Inglesa_na_Legisla\%C3\%A7\%C3\% A3o_Educacional_Brasileira

Nes, E. F. (2016). Social Classes in Brazil. https://thebrazilbusiness.com/article/social-classes-in-brazil-1453802521

Pereira, F. M. (2016). From Non-Cultural to Intercultural Principles: a Proposal for English Classes in Brazilian Public Schools. Intercultural Education, 27(6), 577-586. http://dx.doi.org/10.1080/14675986.2016.1249634

Rajagopalan, K. (2003). The Ambivalent Role of English in Brazilian Politics. World Englishes, 22(2), 91-101. https://doi.org/10.1111/1467-971X.00281 
Silva, F. M. (2015). Dos PCN LE às OCEM: o ensino de língua inglesa e as políticas linguísticas educativas brasileiras. [From the National Curriculum Parameters to the Curriculum Guidelines for Secondary Education: English Language Teaching and Language Policies in Brazilian Education]. Pesquisas em Discurso Pedagógico, 1. https://doi.org/10.17771/PUCRio.PDPe.24801

World Atlas. (2019). What Languages Are Spoken in Brazil? https://www.worldatlas.com/articles/what-languages-are-spoken-in-brazil.html

\section{Copyrights}

Copyright for this article is retained by the author(s), with first publication rights granted to the journal.

This is an open-access article distributed under the terms and conditions of the Creative Commons Attribution license (http://creativecommons.org/licenses/by/4.0/). 